\title{
Analysis of Food Expenditure in Perak
}

\section{Choong Foon Yin, Fatimah-Salwa Abd. Hadi}

To Link this Article: http://dx.doi.org/10.6007/IJARBSS/v11-i6/10158

DOI:10.6007/IJARBSS/v11-i6/10158

Received: 06 April 2021, Revised: 29 April 2021, Accepted: 16 May 2021

Published Online: 13 June 2021

In-Text Citation: (Yin \& Hadi, 2021)

To Cite this Article: Yin, C. F., \& Hadi, F.-S. A. (2021). Analysis of Food Expenditure in Perak. International Journal of Academic Research in Business and Social Sciences, 11(6), 365-379.

\section{Copyright: (c) 2021 The Author(s)}

Published by Human Resource Management Academic Research Society (www.hrmars.com)

This article is published under the Creative Commons Attribution (CC BY 4.0) license. Anyone may reproduce, distribute, translate and create derivative works of this article (for both commercial and non-commercial purposes), subject to full attribution to the original publication and authors. The full terms of this license may be seen

at: http://creativecommons.org/licences/by/4.0/legalcode

\section{Vol. 11, No. 6, 2021, Pg. 365 - 379}

Full Terms \& Conditions of access and use can be found at http://hrmars.com/index.php/pages/detail/publication-ethics 


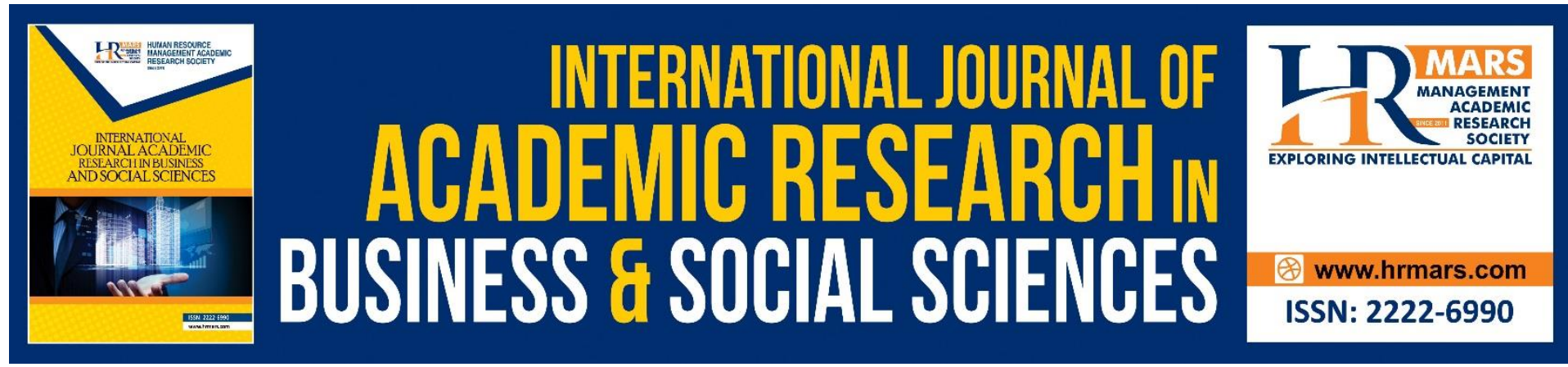

\title{
Analysis of Food Expenditure in Perak
}

\author{
Choong Foon Yin, Fatimah-Salwa Abd. Hadi \\ Faculty of Management and Economics, Universiti Pendidikan Sultan Idris, 35900 Tanjung \\ Malim, Perak, Malaysia \\ Email: fatimahsalwa@fpe.upsi.edu.my
}

\begin{abstract}
This study aims to analyze food expenditure among the community in Perak. There are three objectives targeted in this study including: 1 ) identify the level of food expenditure, 2) identify the relationship between demographic factors with food expenditure and 3) analyze the factors influencing food expenditure. This quantitative study used a set of questionnaire as an instrument to obtain the necessary information. A total of 206 respondents were involved in this study through snowball sampling. All selected respondents were heads of families living in the state of Perak. Descriptive analysis showed that the mean food expenditure was RM1,301.89. In addition, the findings of the study also showed that there was significant relationship between age and education with food expenditure. The significance value was 0.05 , multiple regression analysis showed that consciousness, personal and religious factors were significantly positive while social factors were significantly negative. Media was found as the only factor that was not significant. In conclusion, food spending in the state of Perak is high and this situation is driven by many factors. This included the supply of food at affordable prices, the function of the authorities to promote food, high supply of ready and unfinished food and so on. The implications of the study have highlighted the importance of expenditure planning especially to every head of the family. This is important to ensure that the residents in Perak have sufficient knowledge on the selection of good healthy foods.
\end{abstract}

Keywords: Food, Expenditures, Prices, Perak.

\section{Introduction}

Malaysia is known as a country with racial and cultural diversity. This situation leads to the existence of a variety of unique and delicious foods. According to Ho (2020), food diversity has made Malaysia one of the food paradises and the demand for food is increasing every year. Food is not only a catalyst for unity for Malaysians, but also a driver of the country's economy. In this regard, Perak is also one of the states in Malaysia that offer a variety of food. According to Muhammad (2016), the state of Perak also has a unique food diversity based on district. To introduce the diversity of these types of food, various efforts have been made by Tourism Perak Malaysia together with Youth, Sports, Communication and Multimedia Perak (BSKM). This includes producing a short video "Perak Food Hunter" themed on food in the state of Perak (Mohamed, 2021). In addition, Perak Food Trail program was implemented in collaboration with the Malayan Railway Berhad (KTMB). In this program, participants will ride the Intercity special event coach from Kuala Lumpur to Ipoh (Radzi, 2015). Efforts to promote 
food in Perak have had a positive impact, especially in the economic sector. The demand for food has not only soared but also caused an increase in food prices.

Along with the progress made, dietary practices have changed in both developing and developed countries. Changes in dietary practices are also changing consumer spending patterns. Households have the option of getting food, either cooking their own or buying ready-to-eat food. Competitive ready-to-eat food prices cause demand to increase over time. In addition, work commitments and a variety of ready-to-eat options also contribute to the increased demand for ready-to-eat foods. In Australia for example, spending on ready meals increased to $34 \%$ of total food spending in 2016 compared to only $26.4 \%$ in 1993 (Hogan, 2018). The situation is also happening in other developed countries such as the United States due to the increase in the volume of ready food production, efficient ready food processing and distribution systems, convenient purchasing methods and the opportunity to enjoy fast food (Knorr et al., 2018, Baker \& Friel, 2016).

There is no denying that these changes have led to a significant increase in rates of obesity, diabetes, cancer and other chronic diseases in Australia. In the context of Malaysia, especially in Perak, there are various types of food options that are easily available. Apart from promotion, the Perak state government also took the initiative by providing courses and training to entrepreneurs who produce food. These courses and trainings aim to improve the quality and distribution of food. In addition to having a wide selection of ready meals, Perak also has a readily available source of raw food. Perak's strategic position as close to the sea allows them to get food supplies such as fish at affordable prices. Idle lands are also cultivated by the state government for vegetable cultivation projects to ensure adequate food supply, especially for the market in Perak (Perak State Government Secretary, 2017).

Although Perak has a wide range of food options whether ready-to-eat or raw food, studies focusing on food expenditure are rarely conducted. A study on food purchase options should be done because of the occurrence of various health problems in Perak such as obesity. According to Abdullah (2018), Raja Permaisuri Bainun Hospital Ipoh, Perak has established a Bariatric Clinic to provide exposure on obesity and how to overcome it. Since the clinic was established in September 2014, a total of 1658 patients have been registered, 85 patients managed to lose weight between 40-50 percent while 70 patients lost weight up to 40 percent. The majority of these obese patients are Perak resident. Therefore, studies related to food expenditure need to be implemented. In addition, the factors that influence food expenditure should also be studied, especially among the Perak community of different races and religions.

\section{Literature Review}

Food in Arabic is referred to as al-ta 'am (jamak al-at imah), which is something taken by humans as a basic need for survival (Abd Allah et. al, 1984). Meanwhile, food in English is described as an item used for food or drink for humans or other animals or an item used for a component of any other item (Fortin, 2011). Meanwhile, food is also defined as everything that is eaten either in solid or liquid form to obtain energy and physical health (Man \& Yahya, 2014). The USDA Food Safety and Inspection Service (2014) divides food into ready-to-eat and not ready-to-eat food. Ready-to-eat food refers to food that appears from the outside to be fully cooked until it is safe to eat, or normally eaten without further preparation, and the 
packaging label also does not include further cooking instructions. Meanwhile, frozen food is also counted as ready food because it has already been cooked and only involves a minimal process to prepare it.

Rounds et. al. (2013) referred not ready-to-eat food as foods that contain raw materials, that are not cooked and may contain pathogens that cause foodborne illness. Foods require full cooking before serving because uncooked food may contain pathogens in the ingredients that need to be removed. Food is essential for human survival. It also fulfills the criteria of an individual to pursue the goal of life. According to Maslow (1954), there are five basic needs arranged in a hierarchical order. The theory related to food is Maslow's Theory of Needs which mentions food in the main human need which is physiological needs.

According to Ismail (2009), Consumer Behavior Theory is a decision-making process for the purchase of goods and services based on the increased level of satisfaction by end users. This process often involves several questions such as what, when, where, why and how consumers buy. Consumer purchasing decisions can be stimulated by marketing stimuli and environmental stimuli. Marketing stimulus is a mix of marketing such as product, distribution, pricing, and promotion. Environmental stimuli refer to the economy, culture, technology and politics. All these stimuli will be taken into account in making the decision to buy.

The study by Birari and Patil (2014); Seman and Ahmad (2017) has stated that two demographic factors influence food expenditure. Oostenbach's (2020) study showed that residential location will influence spending on ready meals. According to Marquis and Manceau (2007), a study conducted in relation to apartment accommodation, amenities and budget for food were found to be major factors to food choices. Reid, Lloyd and O'brien (2017) state that home space will influence households to choose whether to dine out in restaurants, hotels and clubs for social interaction between friends and family. Different residential location can alter different raw materials which will lead to changes to the nutrients found in food (Shove, Pantzar and Watson, 2012; Maller, 2015).

In the study of Kumar et. al. (2020), there are many factors such as ethnic group, family size and age of household head. Television and telephone ownership, increased remittances and cash transfers are also factors. In addition, poor households and non-poor households, illiterate parents, households with illiterate father, crop diversity, net buyers from urban areas, increase in agricultural land, presence of a mother working in the agricultural sector, household livestock ownership, agricultural wages, average time required to reach paved roads are also the factors. The rest of the factors are access to irrigation, household who own livestock, increase in average annual non-agricultural wage, increase in average agricultural wage, access to paved roads, increase in percentage of households with access to irrigation, households in hilly districts and in provinces, increase in road density and urban population density will affect spending food.

Kirkpatrick and Tarasuk (2003) noted that studies in several countries have noted income differences in influencing food expenditure. There is some evidence to suggest that the adoption of a healthy diet is complicated for low-income Canadians with the high cost of some of the recommended foods (Travers, 1997). In a study by Kirkpatrick and Tarasuk (2003), low-income households would spend less money on food (in restaurants and in stores) 
compared to high-income households. Horton and Campbell (1990) noted that, based on an analysis of data from the 1984 FOODEX survey, low-income households were more likely to buy cheaper food brands in certain types of food in order to spend more efficiently. Badun et al. (1995) also concluded that parents in low-income communities in Ontario have low expenditures for food containing calcium, iron, zinc, vitamin A and folate. Further, Evers and Hooper (1995) found that children in low-income Ontario communities may be at risk of spending on foods containing insufficient calcium and vitamin A while Mclntyre et al. (2001) found that low-income women and children in the Atlantic region have a lower chance of spending on foods containing calcium, vitamin A, vitamin D and folate.

Analysis of household food expenditure data provides valuable insights into the influence of social and economic conditions on food access and choice in populations (Simeon and Patterson, 1996; Trichopoulou et. Al., 1996). Dubois and Girard (2001) noted a strong social gradient in influencing the expenditure of calcium -containing foods reported among women and men. Ghadirian and Shatenstein (1996) reported that low calcium intake was associated with low income among Montreal women. Studies of women in families using food banks in Toronto recorded very low levels of spending on foods containing calcium (Travers, 1996) and spending on limited dairy products (Tarasuk, 2001), while Jacobs Starkey et al. (1999) found low levels of calcium, vitamin A and zinc among food bank consumers in Montreal.

Extrinsic factors can be strong indicators that indicate high levels of emotion such as brand, price, convenience and so on (Kardes et al., 2004). Consumers with a low level of understanding of relevant knowledge about a particular product are more dependent on extrinsic factors (Yin et al., 2007). Many researchers have found that price factors will influence spending. According to Olson (1977), prices are explained through two categories namely financial and non-financial. Finance can be defined when price is usually related to a statement of money while the non-monetary definition that is price refers to a buyer's effort to find information about a product before they shop (Li and Green, 2011). From a consumer perspective, price refers to what consumers are willing to use money to obtain goods or services (Zeithaml, 1982). The meaning of price is different when price is considered from various demographic perspectives such as marital status, gender, employment status and awareness (Zeithaml, 1988). Over the past few decades, there has been an increase in attention to packaging and external features as these factors have been found to influence consumer spending decisions (Rezaei, 2014) making them an important element for marketers, designers and even food producers. $90 \%$ of consumers make their shopping decisions after checking the front package label and $85 \%$ of consumers make their shopping decisions without looking at alternative products (Urbany, Dickson and Kalapurakal, 1996).

Mccracken and Mackln (1998) studied the influence of packaging such as color, picture, design, size and shape of certain products in influencing consumer spending decisions while Simmonds and Spence (2017) studied about nutritional information printed on product packaging. This suggests that it is important to understand about how packaging conveys messages among consumers. According to Rohm and Swaminathan (2004), convenience is defined as an advantage over effort and time savings by consumers rather than purchasing goods. This explains the shorter time and less energy required to achieve the desired results other than the reduced use of time (Costa et al., 2007). Perceived convenience benefits 
including a reduction in food preparation stress, especially among urban dwellers with busy lifestyles and the possibility of faster preparation have been seen as unique food added value. Saving time for easy access to food has become an important element of daily life (Celnik et al, 2012).

Lampila and La"hteenma"ki (2007) in turn argue that, consumers will tend to spend on ready meals if they are aware of the availability of ready meals which improved access to its facilities (Prasad and Aryasri, 2008). Findings from various perspectives indicate that consumers of ready-made foods are always in a dilemma resulting in unpredictable spending decisions (Bulsara and Trivedi, 2016). The increase in health problems makes the nutritional information factor a significant factor (Selvarajn, 2012) and has been an important element in spending decisions. However, Onozaka et al (2014) showed that persistent gaps exist in understanding consumer behavior in acquiring, understanding and using nutritional information in influencing the desire to spend.

To analyze the factors that influence spending, the religious aspect is rarely given attention. In general, this aspect is closely related to consumers especially in decision making. Religious teachings such as not to waste while shopping should be taken into account. Essentially, religious and spending factors are inseparable (Diesen, 2014; Khan and Kirmani, 2018).

\section{Research}

\section{Methodology}

This study uses quantitative methods and involves 206 respondents who are residents of Perak who are head of the family and working. Respondents in this study were selected by taking snowball sampling. Questionnaires in the form of hard copies and Google Form links were distributed to respondents to gather information.

To ensure that the research instrument, namely the questionnaire, was suitable for use, advisory services were obtained from several experts to confirm its content. The questionnaire used in this study has been validated by several expert lecturers and officials. Modifications to the research instrument were done based on the objectives of the study and have been confirmed by several lecturers from Universiti Pendidikan Sultan Idris (UPSI). In addition, three heads of family living in Perak were also involved in this validation process.

In this study, food expenditure was used as the dependent variable while awareness, media, social, religious, and personal became independent variables. After collecting the questionnaires, the data were analyzed descriptively and inferentially. To identify the food expenditure of the residents of Perak, descriptive analysis of mean and frequency was used. Furthermore, multiple regression tests were used to analyze the factors influencing food expenditure among the residents of Perak.

\section{Findings}

\section{Respondent Profile}

Descriptive analysis was conducted to examine the profiles of the respondents using frequency and percentage. Table 1 below shows the findings of the descriptive analysis of the profile of respondents on the level of food expenditure among the community in Perak. Based 
on the table, the majority of respondents in this study consisted of 106 women (51.5\%) and 100 men (48.5\%) percent. In terms of age, most of the respondents of this study are aged between 31 to 40 years which is $82(39.8 \%)$ followed by respondents aged between 21 to 30 which is $76(36.9 \%)$ while only 4 respondents (1.9\%) aged 20 years and below.

For the ethnicity, there were 72 (35.0\%) Malay respondents followed by the 67 Chinese (32.5\%), 53 Indians (25.7\%) and 14 minority (6.8\%). In terms of religion, there were 72 Muslim (35.0\%) respondents, followed by 57 Buddhist (27.7\%), 48 (23.3\%) Hindus, 11 Christian (5.3\%) and $18(8.7 \%)$ from other religions. There were 4 respondents (1.9\%) with Doctor of Philosophy as the highest level of education, 65 Master's Degree holders (31.6\%). Majority of respondents have a Bachelor's Degree which was 84 (40.8\%). A total of 31 respondents (15.0 percent) have an education level at the STPM level or equivalent. The employment analysis of the respondents of this study consists of four categories namely family business, own business, government and private. The results of this analysis showed that 61.2 percent of the respondents worked in the private sector, 17.5 percent worked in the government sector and 17.5 percent had their own businesses and 3.9 percent had family businesses.

In addition, an analysis was also made on the monthly family income of the respondents. The analysis showed that most of the respondents of the study, namely 33.5 percent earned a monthly income of RM2,001 to RM3,000 followed by 31.6 percent of respondents who earned a monthly income of $\mathrm{RM} 3,001$ to $\mathrm{RM} 4,000$ and 19.0 percent of respondents who earned a monthly income of more than RM5, 001. Analysis of family dependents shows that most families have 3 dependents which is 50.5 percent of respondents followed by 2 dependents which is 35.0 percent of respondents while only a small number of respondents have 6 dependents which is 1.0 percent of respondents. Analysis of residential location, the majority of respondents live in suburban areas which is 36.4 percent followed by 34. percent of respondents who live in rural areas while only 29.6 percent of respondents who live in urban areas. 
INTERNATIONAL JOURNAL OF ACADEMIC RESEARCH IN BUSINESS AND SOCIAL SCIENCES Vol. 11, No. 6, 2021, E-ISSN: 2222-6990 @ 2021 HRMARS

Table 1: Profile of Respondents

\begin{tabular}{|c|c|c|c|}
\hline \multirow[t]{2}{*}{ Information } & \multirow[t]{2}{*}{ Category } & \multicolumn{2}{|l|}{ Total } \\
\hline & & Frequency $(n=206)$ & Percent (\%) \\
\hline \multirow[t]{2}{*}{ Gender } & Male & 100 & 48.5 \\
\hline & Female & 106 & 51.5 \\
\hline \multirow[t]{5}{*}{ Age } & $<20$ years old & 4 & 1.9 \\
\hline & 21 - 30 years old & 76 & 36.9 \\
\hline & 31 - 40 years old & 82 & 39.8 \\
\hline & 41 - 50 years old & 29 & 14.1 \\
\hline & $>51$ years old & 15 & 7.3 \\
\hline \multirow[t]{4}{*}{ Race } & Malay & 72 & 35.0 \\
\hline & Chinese & 67 & 32.5 \\
\hline & Indian & 53 & 25.7 \\
\hline & Others & 14 & 6.8 \\
\hline \multirow[t]{5}{*}{ Religion } & Islam & 72 & 35.0 \\
\hline & Buddha & 57 & 27.7 \\
\hline & Hindu & 48 & 23.3 \\
\hline & Christian & 11 & 5.3 \\
\hline & Others & 18 & 8.7 \\
\hline \multirow{5}{*}{$\begin{array}{l}\text { Highest Level of } \\
\text { Education }\end{array}$} & SPM or equivalent & 22 & 10.7 \\
\hline & STPM or equivalent & 31 & 15.0 \\
\hline & Degree & 84 & 40.8 \\
\hline & Master's Degree & 65 & 31.6 \\
\hline & Doctor of Philosophy & 4 & 1.9 \\
\hline \multirow[t]{4}{*}{ Occupation } & Family & 8 & 3.9 \\
\hline & Self & 36 & 17.5 \\
\hline & Government & 36 & 17.5 \\
\hline & Private & 126 & 61.2 \\
\hline \multirow{5}{*}{$\begin{array}{l}\text { Monthly } \\
\text { (RM) }\end{array}$} & $1001-2000$ & 3 & 1.5 \\
\hline & $2001-3000$ & 69 & 33.5 \\
\hline & $3001-4000$ & 65 & 31.6 \\
\hline & $4001-5000$ & 30 & 14.6 \\
\hline & $>5001$ & 39 & 19.0 \\
\hline \multirow{5}{*}{$\begin{array}{l}\text { Dependents } \\
\text { (persons) }\end{array}$} & 2 & 72 & 35.0 \\
\hline & 3 & 104 & 50.5 \\
\hline & 4 & 25 & 12.1 \\
\hline & 5 & 3 & 1.5 \\
\hline & $>6$ & 2 & 1.0 \\
\hline \multirow{3}{*}{$\begin{array}{l}\text { Residential } \\
\text { Location }\end{array}$} & Urban & 61 & 29.6 \\
\hline & Suburbs & 75 & 36.4 \\
\hline & Rural & 70 & 34.0 \\
\hline
\end{tabular}

Source: Questionnaire, 2019 


\section{Food Expenses}

Food is an essential component of basic human needs. This section analyzed the respondents' food expenditure. In this section there are three main items of analysis. The first is the component of respondent's basic necessities expenditure, then followed by food purchase options and total food expenditure.

Table 2: Respondents' Basic Needs Expenditure Components

\begin{tabular}{ll}
\hline Information & Mean (RM) \\
\hline Food & $1,301.89$ \\
Residence & 897.57 \\
Education & 413.11 \\
Health & 338.76 \\
Clothes & 216.89 \\
\hline
\end{tabular}

Source: Questionnaire, 2019

Table 2 shows the mean values for each component of respondents' basic necessities expenditure for a period of one month. Basic needs contain 5 main components namely food, clothing, shelter, education and health (Ibrahim, 2020 and Abdul Karim et. Al., 2017). The findings showed that food had the highest mean value of RM1,301.89 compared to other components. This was followed by expenditure on accommodation with a mean value of RM897.57. Meanwhile, expenditure on clothing and health had the lowest mean value of RM216.89 and RM338.76 respectively. Apart from being the most important component of basic necessities, the high price of food or raw materials and the large number of dependents have resulted in the total expenditure on food being higher than other components. Nevertheless, the findings of this study differed from the findings of the Department of Statistics Malaysia (2020) which showed that food is the second highest expenditure after the categories of housing, water, electricity, gas and other fuels.

There are two choices for the respondents to get food, either buy ready-to-eat food or buy raw materials and cook at home as shown in Table 3 . The findings showed that the majority of respondents (60.2\%) chose to buy raw materials and prepared their own food instead of buying ready-to-eat food. This situation occured because respondents had a high awareness that the cost of preparing their own food was cheaper, cleaner and healthier. This finding was in contrast to the results of the study of Ab Rahman and Wahid (2016) who found that the majority of respondents choose to buy ready-to-eat meals.

Table 3: Food purchase options

\begin{tabular}{lll}
\hline Food purchase options & Frequency $(\mathrm{n}=206)$ & Percent $(\%)$ \\
\hline Buy ready-to-eat food & 82 & 39.8 \\
Buy ingredients for cooking at home & 124 & 60.2 \\
\hline Source: & Questionnaire, &
\end{tabular}

Meanwhile, Table 4 shows the mean value of food expenditure according to the residential location of the respondents, namely urban, suburban, and rural. Overall, the mean value of food expenditure in the city was higher compared to the suburbs and rural areas. 
Nevertheless, the mean value showed that the purchase of ready meals in rural areas (RM700.50) was higher than the mean value in urban areas (RM602.80) and suburbs (RM521.05). Besides, there were many ready food options in rural areas, cheap ready-to-eat food prices can attract rural respondents to make demand.

Table 4: Total food expenditure

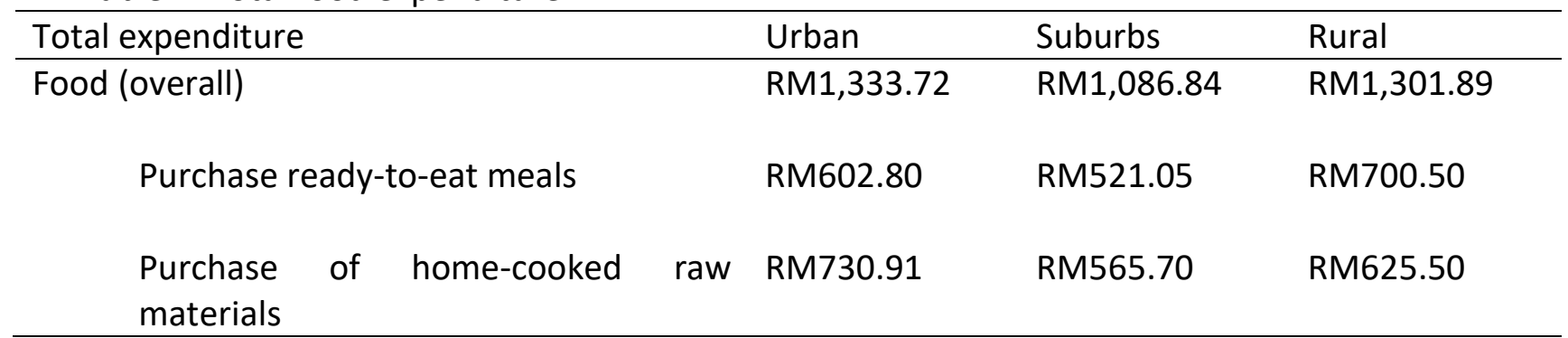

Source: Questionnaire, 2019

Meanwhile, the mean value of respondents' purchases of raw materials in urban areas was higher (RM730.91) compared to suburbs (RM565.70) and rural areas (RM625.50). In addition to emphasizing the aspect of choosing clean and nutritious food, respondents in the urban area prefered to prepare their own food due to the high price of ready-to-eat food.

\section{Determinants of Food Expenditure}

Next, this section analyzed the determinants of food expenditure. The criterion variable was total food expenditure while the predictor variables were awareness, media, social, religious, and personal factor. The findings from the regression test analysis are shown through Table 5 below.

Table 5: Multiple Regression Analysis for Food Expenditure

\begin{tabular}{llll} 
Independent Variables & Beta & t value & p value \\
\hline (Constant) & & -7.374 & 0.000 \\
Awareness & 0.283 & 4.292 & 0.000 \\
Media & 0.060 & 0.697 & 0.487 \\
Social & -0.159 & -2.218 & 0.028 \\
Religious & 0.205 & 2.950 & 0.004 \\
Personal & 0.393 & 4.217 & 0.000 \\
& & & \\
\hline$R$ & & 0.683 & \\
$\mathrm{R}^{2}$ & & 0.467 & \\
Adjusted R & 0.453 & \\
\hline
\end{tabular}

a. Dependent Variables: Total Food Expenditure (RM)

*Significant at the $p<0.05$ level

Source: Questionnaire, 2019

Based on the regression test findings shown in table 5 above, there are R, R2 and adjusted $\mathrm{R} 2$ values. The value of $\mathrm{R}$ indicates the relationship between the predictor variable and the criterion variable. In this study, the relationship between predictor variables with total food expenditure in Malaysia is strong (0.683) as described by Chua (2013). 
Furthermore, $\mathrm{R} 2$ is a coefficient that measures the strength of the regression estimated from the sample or measures the strength between linear relationships that is looking at changes in the dependent variables. However, this study did not use such values to assess changes in independent variables that exceed two that is five. Thus, adjusted R2 is used to compensate for R2 which does not take into account the loss of degrees of freedom (df) when the greater the number of effect parameters than the increase in the number of estimated independent variables.

Referring to table 5, the value of $\mathrm{R} 2$ recorded as 0.467 , this means that 46.7 percent of all predictor variables namely awareness, media, social, religious, and personal are contributors to total food expenditure in Malaysia. Meanwhile, the adjusted R2 value in this study was 0.453 . This indicates that as much as 45.3 percent of the change in the criterion variables was due to changes in the predictor variables namely awareness, media, social, religious, and personal. This means that the combination of the five predictor variables accounted for 45.3 per cent of the variance change in total food expenditure in Malaysia. The beta used in this study is the standardized beta. The standardized beta compares the effect strength of each individual independent variable with the dependent variable. The higher the absolute value of the beta coefficient, the stronger the effect. The standardized beta has the standard deviation as its unit. This means the variables can be easily compared with each other (Lindstrom, 2010).

The results from this regression test have shown that there are only four predictor variables namely awareness, social, religious, and personal are contributors to the total food expenditure in Malaysia. Meanwhile, for the media predictor variable $(t=0.697, p>0.05$ ) has shown an insignificant relationship with total food expenditure in Malaysia because the $p$ value is greater than 0.05 .

Based on the findings shown in the table above, the awareness factor is a significant predictor and can be shown based on the high value of the standard beta coefficient of 0.283 . This means that the awareness factor has a strong impact when compared to the other predictor variables in this study. The awareness factor was found to be the main variable $(t=$ $4.292, p<0.05)$ that was positively significant on food expenditure. This indicates that the respondents have spent according to their awareness of food selection based on food health and hygiene. The higher the awareness of the purchase of good and nutritious food, the higher the level of food expenditure spent.

Based on the regression test results, the media factor is a non-significant variable and can be shown based on a low standard beta coefficient value of 0.060 and a significant value greater than the alpha value, which is 0.487 and has a $t$ value of 0.697 . A $p$ value is higher than 0.05 has indicated that the media factor has an insignificant relationship to the dependent variable. Therefore, media factors do not affect the level of food expenditure in Malaysia.

Based on the results of regression tests that have been conducted, the analysis found that social factors are a significant variable and it is shown based on the value of a high standard beta coefficient of -0.159 . The high value of the standard beta coefficient indicates that the social variable has a strong impact when compared to the other predictor variables 
in this study. For social factors, the significant value is lower than 0.05 which is 0.028 . Social factors were also found to be significant but were negative $(t=2.218, p<0.05)$. Society does not spend according to the liking of peers and family. The lower the social factors are met, the higher the level of food expenditure spent.

For religious factors, based on the results of regression tests that have been conducted, found that religious factors are a significant variable and it is shown based on the value of a high standard beta coefficient of 0.205 . The high value of the standard beta coefficient indicates that the religious variable has a strong impact when compared to the other predictor variables in this study. Religious factors were also found to be positively significant $(t=2.950, p<0.05)$ to the level of food expenditure. Religious teachings play an important role in influencing food spending, religious teachings like not wasting food, leaving out foods that are harmful to health, and not choosing certain types of food. The higher the religious factor is met, the higher the level of food expenditure spent to meet the necessities of life.

As for personal factors, based on the results of regression tests that have been conducted, it was found that personal factors are a significant variable and it is shown based on the value of a high standard beta coefficient of 0.393. The high value of the standard beta coefficient indicates that the personal variable has a strong impact when compared to the other predictor variables in this study. Personal factors were also found to be positively significant $(t=4.217, p<0.05)$ contributing to the level of food expenditure. Communities buy food based on preference, satisfaction, easy payment methods, and nearby food stores. The higher the community's satisfaction with preferences, payment methods, and food store distance, the higher the level of food spending spent.

The awareness factor is the most influential factor because today's society is becoming increasingly concerned about health care. More and more individuals are starting to exercise every day and stay on for a long period of time. More and more health care products are being sold in the market. All of these situations have reflected society's awareness of health care, as well as nutritious food choices.

\section{Conclusion}

In conclusion, awareness and knowledge should be disseminated among the society so that they can control their cravings in food expenditure. Non-essential food elements can be neglected to maintain the frugal attitude instilled in the society. The implications of the study highlight the importance of expenditure planning especially to every head of the family. This is important to ensure that the residents in the state of Perak have sufficient knowledge about good food choices for health.

Spending according to one's liking is not a kind of offense but it will cause serious problems if it is beyond the level of one's ability and entangled with various problems. Food that symbolizes the needs of a family should not be associated with negative things. Therefore, the attitude of people who like to spend on less important aspects including food should be avoided to avoid any harm in the future. 
The findings of this study are important to some parties to play their role. The government has a role to give awareness to the community to enjoy healthy food in solving the problem of obesity and food prices. Government interventions such as controlling food or petrol prices and formulating policies that truly protect consumers will ensure public health can be guaranteed. The head of the family will get accurate knowledge about spending and food choices, a modest attitude towards spending will be able to ensure well -being and reduce waste. Disclosure of total food expenditure can also help the community be more sensitive when choosing and spending according to need. The amount of food expenditure will cause the community to support each other to get healthy and balanced food at an affordable price.

\section{References}

Ab Rahman, N. H., \& Wahid, H. (2016). Pola perbelanjaan makanan asasi golongan miskin: kajian di Negeri Selangor. Prosiding Seminar Pengajian Islam (SEPIS) 2016, 128-136. http://www.ukm.my/hairun/kertas\%20kerja/sefis\%202016\%20haslina.pdf

Abd Razak, S. M. (2014). Faktor dan implikasi tiada jaminan kedapatan makanan dalam kalangan mahasiswa yang menerima bantuan kewangan di institusi pengajian tinggi awam (IPTA). Masters Thesis, Universiti Putra Malaysia. http://psasir.upm.edu.my/id/eprint/39726/1/FEM\%202014\%206\%20edit.pdf

Abd. Talib, R., Lim, S. H., Fakhrurazi, H., Buhari, S. S., \& Poh, B. K. (2013). Penilaian media bercetak untuk pendidikan pemakanan kanak-kanak berlebihan berat badan dan obes. Jurnal Sains Kesihatan Malaysia, 11(2), 55-62.

http://ejournal.ukm.my/jskm/article/view/5337

Abdul Karim, N. A.-H., Rambeli@Ramli, N., Hashim, A., Hashim, E., \& Mohd Kornine, N. H. (2017). Analisis perbelanjaan asas bulanan penjawat awam di Daerah Larut Matang dan Selama, Negeri Perak. Management Research Journal, 7(1), 125-138. https://ejournal.upsi.edu.my/index.php/MRJ/article/view/1402/1011

Abdullah, M. A., \& Ali, N. (2011). Amalan pemakanan dalam kalangan pelajar universiti dan implikasinya terhadap pembelajaran. Jurnal Personalia Pelajar, 14, 59-68.

Abdullah, R. (2018). HRPB bantu pesakit atasi masalah obesiti. Utusan Online. http://www.utusan.com.my/berita/wilayah/perak/hrpb-bantu-pesakit-atasi-masalahobesiti-1.782357

Agresti A. (1990). Categorical Data Analysis. John Wiley and Sons.

Ahmad, I. (2018). Pesakit obesiti meningkat. Sinar Harian. https://www.sinarharian.com.my/edisi/perak/pesakit-obesiti-meningkat-1.818779

Ang, K. H. (2016). Pengenalan rangkakerja metodologi dalam kajian penyelidikan: satu kajian kes. Malaysian Journal of Social Sciences and Humanities, 1(1), 17-23. https://doi.org/10.47405/mjssh.v1i4.30

Azeman, A. R., Mohd Raduan, N. F., \& Othman, N. F. (2016). Pemilihan makanan di kalangan pelajar Kolej Universiti Islam Melaka: satu tinjauan. Jurnal Hospitaliti Dan Jaringan, 1, 71-80. https://journal.kuim.edu.my/index.php/JHN/article/view/342/292

Baskerville, P. (2011). What are expenses in accounting? Saylor Academy. https://www.saylor.org/site/wp-content/uploads/2011/12/BUS103-EXPENSES.pdf

Bryman, A., \& Cramer, D. (2005). Quantitative data Analysis with SPSS 12 and 13: A guide for social scientists. Psychology Press. 
Chan, Y. T., Safii, N. S., \& Chan, W. L. (2017). Pengaruh sosial dan multimedia terhadap pilihan snek kegemaran atlet ketahanan. Jurnal Sains Kesihatan Malaysia, 15(2), 145-151. https://pdfs.semanticscholar.org/bda9/2afdaf5925042d1c6277fd7f8f91a1c74519.pdf

Che Soh, N. (2018). Obesiti di Malaysia meningkat. Utusan Online. https://www.utusan.com.my/rencana/forum/obesiti-di-malaysia-meningkat-1.669069

Chua, Y. P. (2011). Kaedah dan statistik penyelidikan: Kaedah penyelidikan. Mcgraw-Hill Education.

Chua, Y. P. (2013). Kaedah dan statistik penyelidikan buku 3: Asas statistik penyelidikan: Analisis. McGraw-Hill (Malaysia) Sdn. Bhd.

Cliff, N. (1987). Analyzing multivariate data. Harcourt College Pub.

Dodge, Y. (2008). The Concise Encyclopedia of Statistics. Springer Science + Business Media.

Endut, W., Ahmad, F., \& Asri, M. N. (2007). Gelagat permintaan pengguna terhadap makanan luar: kajian kes di Ipoh, Klang dan Seremban. Malaysian Journal of Consumer and Family Economics, 10(1), 85-97.

https://www.researchgate.net/publication/288592487_Gelagat_Permintaan_Penggun a_Terhadap_Makanan_Luar_Kajian_Kes_di_Ipoh_Klang_Fan_Seremban

Everitt, B. S., Skrondal, A. (2010). The Cambridge dictionary of statistics, Cambridge University Press.

Fatimah. (2017). Semua pihak perlu jaya matlamat kempen mencegah obesiti. Utusan Borneo Online. https://www.utusanborneo.com.my/2017/03/16/semua-pihak-perlu-jayamatlamat-kempen-mencegah-obesiti

Gillham, B. (2000). Developing a Questionnaire (Real World Research) (1st ed.). Continuum, Paston PrePres Ltd.

Hamzah, A. (2010). Kaedah kualitatif dalam penyelidikan sosiobudaya. Jurnal Pengajian Media Malaysia, 6(1), 1-10. http://www.myjurnal.my/filebank/published_article/14276/Article1JPMM2004.pdf

Hussain, N. (2015). Sekuriti makanan dan pemakanan dalam kalangan pelajar di institusi pengajian tinggi sekitar Kota Kinabalu. Thesis Ijazah Sarjana Muda. Universiti Malaysia Sabah. http://eprints.ums.edu.my/14669/

Ibrahim, M. F. (2020). Perbandingan agihan zakat sebagai alat kewangan sosial islam bagi membantu golongan Al-Gharimin oleh Lzs dan Baitulmal Maiwp. International Journal of Islamic Economics and Finance Research, 3(2), 197-209.

https://ijiefer.kuis.edu.my/ircief/article/view/38

Jabatan Perangkaan Malaysia. (2017). Laporan penyiasatan perbelanjaan isi rumah 2016. https://www.dosm.gov.my/v1/index.php?r=column/cthemeByCat\&cat=323\&bul_id= WnZvZWNVeDYxKzJjZ3RIUVVYU2s2Zz09\&menu_id=amVoWU54UTI0a21NWmdhMjFM MWcyZz09

Jabatan Perangkaan Malaysia. (2020). Laporan penyiasatan perbelanjaan isi rumah 2019. https://www.dosm.gov.my/v1/index.php?r=column/cthemeByCat\&cat=323\&bul_id=c 3JpRzRqeTNPamMxL1FpTkNBNUVBQT09\&menu_id=amVoWU54UTI0a21NWmdhMjF MMWcyZz09

Kementerian Kesihatan Malaysia. (2015). Non-communicable diseases, risk factors and other health problems (MOH/S/IKU/52.15(RR)).

https://www.moh.gov.my/moh/resources/nhmsreport2015vol2.pdf

Kwame Sundaram, J., Tan, Z. G., \& Khalidi, J. R. (2019). Achieving food security for all malaysians. Khazanah Research Institute, 7-67. 
http://www.krinstitute.org/assets/contentMS/img/template/editor/Discussion\%20Pa per_Achieving\%20Food\%20Security\%20for\%20all\%20Malaysians.pdf

Law, L. S. (2013). Factors associated with body weight status among 15-17 year old schoolgoing adolescents In Sibu, Malaysia. Masters Thesis, Universiti Putra Malaysia. http://psasir.upm.edu.my/id/eprint/38651

Lim, W. Y. (2013). Pengaruh saiz hidangan dan pengambilan tenaga daripada makanan terhadap rasa kekenyangan di kalangan pelajar sekolah sains makanan dan pemakanan. Universiti Malaysia Sabah. http://eprints.ums.edu.my/9852/

Lindstrom, D. (2010). Schaum's easy outline of statistics. McGraw-Hill Education.

Muhammad, F., Abdul Razak, A., Hussin, M. Y., \& Abdul Hadi, F. S. (2015). Kehidupan kelas menengah Malaysia: Satu kajian kes mengenai corak perbelanjaan guru dalam pemilikan aset dan pelaburan kewangan. Malaysian Journal of Society and Space, 11(11), 1-13. http://ejournal.ukm.my/gmjss/article/view/18895

Noorazam, N. (2016). Masih ramai rakyat Malaysia terbeban dengan kos harga makanan tinggi. Astro Awani. https://www.astroawani.com/berita-bisnes/masih-ramai-rakyatmalaysia-terbeban-dengan-kos-harga-makanan-tinggi-115437?amp $=1$

Harun, R. K. W. (2015). Pengaruh pengetahuan, sikap, amalan dalam pemakanan dan aktiviti fizikal terhadap status kesihatan guru pelatih IPGM. Post-Doctoral Thesis, Universiti Malaysia Sabah. http://eprints.ums.edu.my/id/eprint/19753

Saleh, N. (2013). kesedaran terhadap amalan pemakanan seimbang dalam kalangan pelajar politeknik Merlimau, Melaka: Satu tinjauan. Masters Thesis, Universiti Tun Hussein Onn Malaysia. http://eprints.uthm.edu.my/id/eprint/5351/ 